\title{
WATER QUALITY ASSESSMENT OF TEKALA RIVER, SELANGOR, MALAYSIA
}

\author{
HANAFIAH, M. M. ${ }^{1}{ }^{*}-$ YUSSOF, M. K. M. ${ }^{1}$-HASAN, M. ${ }^{1}$-ABDUlHASAN, M. J. ${ }^{1}-$ TORIMAN, M. E. $^{2}$ \\ ${ }^{I}$ School of Environmental and Natural Resource Sciences, Faculty of Science and \\ Technology, Universiti Kebangsaan Malaysia, 43600 UKM Bangi, Selangor, Malaysia \\ ${ }^{2}$ School of Social, Development and Environmental Studies, Faculty of Social Sciences and \\ Humanities, Universiti Kebangsaan Malaysia, 43600 UKM Bangi, Selangor, Malaysia \\ *Corresponding author \\ e-mail:mhmarlia@ukm.edu.my \\ (Received 28 ${ }^{\text {th }}$ May 2018; accepted $31^{\text {st }}$ Jul 2018)
}

\begin{abstract}
A study on water quality status of Tekala River, Selangor, Malaysia was conducted at two sampling times. A total of six sampling stations were selected along the river representing the upstream (S1 and S2), the middle stream (S3 and S4) and the downstream (S5 and S6) of the Tekala River. In this study, in-situ and ex-situ analyses were conducted to determine the quality of Tekala River. Physical, chemical and biological parameters included biochemical oxygen demand (BOD), chemical oxygen demand (SOD), ammoniacal nitrogen, total suspended solids (TSS), dissolved oxygen (DO), $\mathrm{pH}$, temperature, total dissolved solid (TDS), salinity, conductivity, Escherichia coli, coliform and macroinvertebrate. According to the result obtained from this study, Tekala River is classified under Class I and Class II based on water quality index and National water quality standard. Two-way ANOVA showed a significant difference between parameters (ammoniacal nitrogen, BOD, pH, temperature, conductivity, DO and TDS) of sampling station. Significant difference was found between ammoniacal nitrogen, $\mathrm{pH}$ and temperature with sampling time. The correlation test revealed that there is relationship between Escherichia coli with ammoniacal nitrogen, temperature and DO. There is also relationship found between coliform with $\mathrm{pH}$ and BOD.
\end{abstract}

Keywords: water quality, biomonitoring, water pollution, water management, biological parameters

\section{Introduction}

Over the centuries, river has been very important to the human society. River has also provided water for irrigation, industrial and domestic uses. Additionally, river plays an important role in assimilating municipal and industrial effluents as well as runoffs from agricultural land and the surrounding area in a watershed (Al-Badaii et al., 2013). The importance of water quality has become a serious matter especially when it involves the assessment of producing the biologically-accepted water system as a whole (Ashraf and Hanafiah, 2017; Muhammad Mansoor et al., 2018). The demand for safe and clean drinking water has increased by leaps and bounds in developing countries that have deteriorated environment (Gelover et al., 2006). The target of the Millennium Development Goal (MDG) which is the 'access to safe drinking water' has set its track globally with about 6.1 billion people in 2010 using improved drinking water sources, an increase of over 2 billion since 1990 (MDG, 2012).

Selangor state can be divided into several districts which are Klang, Kuala Langat, Gombak, Kuala Selangor, Hulu Langat, Hulu Selangor, Petaling, Sabak Bernam and Sepang. Selangor is one of the most populated and industrialized state in Peninsular Malaysia. As the most populated state, rivers in Selangor are facing serious 
contamination due to anthropogenic activities. On the other hand, study by Al-Badaii et al. (2013) found that Semenyih River, Selangor was contaminated with $\mathrm{NH}_{3}-\mathrm{N}$, TSS, COD and $\mathrm{NO}_{3}$ and highly polluted with $\mathrm{PO}_{4}$ and faecal coliform. The sources of contamination were originated from industrial, agricultural, livestock farming and erosion. Mohamad Ali (2010) stated that the main pollution in Selangor River is from poultry farms, wet market activities and industrial wastewater.

Tekala River is a recreational river that has potential to be contaminated with faecal pathogens (such as bacteria and viruses) from human sewage and animal manure. Contaminated recreational water can cause diseases. Therefore, this study aims to measure the water quality status of Tekala River based on the physico-chemical and biological parameters. In view of the above facts, Tekala River has been chosen due to its importance as recreational area. If this river is classified as not safe then further action should be taken to maintain and improve its quality.

\section{Materials and methods}

\section{Study area}

This study was conducted at Tekala River, Selangor, Malaysia (Fig. 1a) within Tekala River Recreational Park (TRRP) that was established since 1982. The highest level of the river leads up to a sparkling waterfall which cascades into a natural rock pool. TRRP is located $13 \mathrm{~km}$ from Semenyih via Jalan Semenyih - Hulu Langat and $50 \mathrm{~km}$ from Kuala Lumpur.

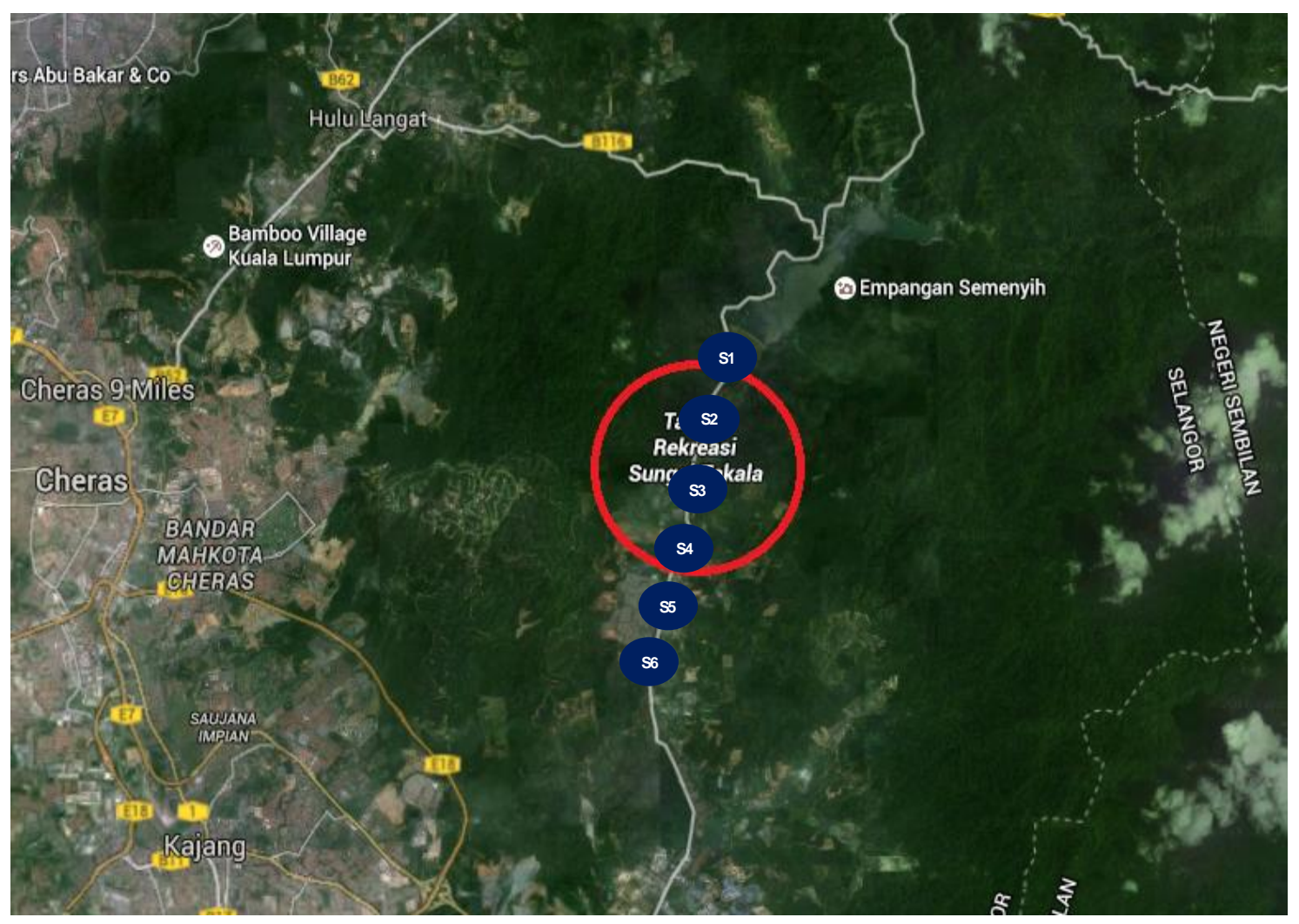

Figure 1. Map of Tekala River and locations of six sampling points 


\section{Measurement of ex-situ parameters}

The water quality index was determined based on the physico-chemical and biological parameters. The parameters include biochemical oxygen demand (BOD), chemical oxygen demand (COD), ammoniacal-nitrogen $\left(\mathrm{NH}_{3}{ }^{-} \mathrm{N}\right)$, total suspended solids (TSS), dissolved oxygen (DO), $\mathrm{pH}$, water temperature, total dissolved solid (TDS), salinity, conductivity, Escherichia coli (E. coli), coliform and macroinvertebrate.

\section{Samples collection and preservation}

Water samples were collected from the selected river and have been collected for two visits in May 2017 and October 2017. A total of 18 water samples were collected from 6 sampling stations and the samples were kept in polyethylene bottles. For BOD sample, another 18 water samples were collected in glass bottle wrapped with aluminium foil. This is to avoid sunlight from penetrating the bottles and react with sample and cause changes in the BOD. During sampling for BOD, no air bubble was observed as it can influence the oxygen content of the sample. All bottles were preserved at $4-10{ }^{\circ} \mathrm{C}$ in an ice box before transported to the laboratory. Preservation of samples need to be done to maintain the actual composition of water samples and can minimize changes in chemical composition during transportation to the laboratory.

DO, water temperature, TDS, salinity, conductivity and $\mathrm{pH}$ values were measured insitu. The COD, TSS, BOD, ammoniacal-nitrogen, E. coli and coliform in the water were analysed in the laboratory using standard procedure of $\mathrm{HACH}$. For macroinvertebrate, samples were collected by using Surber net at 6 stations based on different habitats. All collected samples were transferred into plastic. Then, samples were preserved by using $70 \%$ ethanol in the laboratory for further identification.

Water was kept in dark condition and in temperature around $4-5{ }^{\circ} \mathrm{C}$ to reduce biological activity, to avoid changes and to preserve the actual condition of sample as it is before conducting any analysis. BOD samples were kept in glass bottle preserved at $30{ }^{\circ} \mathrm{C}$ for about 5 days prior to measurement. The use of glass bottle can avoid any changes in activity and microorganism metabolism. Samples for E. coli and coliform test were kept at $4-5{ }^{\circ} \mathrm{C}$ and analysis was conducted at least $4-8 \mathrm{~h}$ after sampling activity.

Biological Oxygen Demand (BOD) was determined by using conventional method by incubating the water samples for a standard time period in incubator at $20{ }^{\circ} \mathrm{C}$ and the oxygen consumption was determined at the end of the incubation period. The first measurement of $\mathrm{DO}$ values $\left(\mathrm{DO}_{1}\right)$ was carried out within $24 \mathrm{~h}$ after sampling by using YSI model 5000. The reading was recorded on a data sheet. The second reading of DO values was determined after 5 days of incubation $\left(\mathrm{DO}_{5}\right)$. BOD values were obtained from the difference in $\mathrm{DO}$ values of the first reading $\left(\mathrm{DO}_{1}\right)$ and the second reading $\left(\mathrm{DO}_{5}\right)$. The BOD value is expressed in milligrams per liter using Equation 1:

$$
\mathrm{BOD}(\mathrm{mg} / \mathrm{l})=\mathrm{DO}_{\text {initial }}-\mathrm{DO}_{\text {final }}
$$

\section{Chemical oxygen demand}

COD was measured by using Reactor Digestion Method approved by USEPA for reporting wastewater analysis. Samples were first homogenized to dissolve containing solids for better representative samples. The homogenized water samples were then added into glass vials containing strong oxidizing agent, potassium dichromate. This mixture was heated for $2 \mathrm{~h}$ at $150{ }^{\circ} \mathrm{C}$ to allow them to react. Colorimetric determination of COD 
with high range using $\mathrm{HACH} \mathrm{DR} / 2010$ was used to measure COD value in the water samples.

\section{Total suspended solid}

Whatmann filter paper with pore size of $0.45 \mu \mathrm{m}$ was put in petri dish each and dried in the drying oven at the temperature of $105^{\circ} \mathrm{C}$ for $1 \mathrm{~h}$. After an hour, the petri dish was taken out and cooled for $30 \mathrm{~min}$ in the desiccator. Before performing filtration of the samples, the weighed filter paper was obtained. This was the initial weight of the filter paper (A). This filter paper then was used in filtration process. For the filtration process, the filter paper was inserted between the Buchner funnel and the suction flask. The water sample in the bottle was shaken and about $200 \mathrm{ml}$ of sample was used in the filtration. After that, the filter paper was put back into petri dish and was dried in the drying oven at $105^{\circ} \mathrm{C}$ and the final weight of the filter paper was recorded (B).

For the calculation (Eq. 2),

$$
x m g / L=\frac{(B-A) X 1000}{\text { Volume of sample used (ml) }}
$$

where,

$\mathrm{A}=$ initial weight of the filter paper (mg)

$\mathrm{B}=$ final weight of the filter paper + soluble solid $(\mathrm{mg})$

\section{Ammoniacal-nitrogen}

Ammoniacal-nitrogen was measured by using HACH DR 2700 based on Nessler Method. $25 \mathrm{ml}$ of sample and $25 \mathrm{ml}$ of deionized water (blank) were transferred into glass cell each and then three drops of mineral stabilizer, three drops of polyvinyl alcohol and $1.0 \mathrm{ml}$ of Nessler reagent were added to each transferred sample. The mixture was measured by using spectrometer at $425 \mathrm{~nm}$. Deionized water was used as blank and the reading was recorded for each sample.

\section{Measurement for biological parameter}

\section{Escherichia coli and coliform}

$100 \mathrm{ml}$ of water sample was used for determination of E. coli and coliform. Water samples were filtered in cellulose membrane filter. After filtration, Eosin Methylene Blue (EMB) agar was added with no air bubbles observed on the agar. The agar was preserved for $22 \pm 2 \mathrm{~h}$ at $35^{\circ} \mathrm{C}$. Organisms that produce a colony with golden-green metallic within $24 \mathrm{~h}$ of incubation on the agar were considered members of E. coli group. While organisms that produce colony with light purple were classified as coliform group.

Quantitative data was obtained by counting the number of each colony formed by assumption that each colony represents one bacterium. Colony of coliform and $E$. coli that grow was counted and expressed in unit of cfu (colony forming unit) (APHA, 1980) and calculated as below (Eq. 3):

$$
\text { E. coli } / 100 \mathrm{ml}=\frac{100 \mathrm{X} \text { Number of colony }}{\text { Volume of sample filtered }(\mathrm{ml})}
$$




\section{Macroinvertebrate}

All the samples from the river were taken to the laboratory for identification process. Sample from different stations were put in different bottles. Each sample was analyzed by identifying specific characteristics for each species such as head shape, body segment and type of wings. Samples that had already been identified were preserved in $70 \%$ ethanol.

\section{Water quality classification}

Classification in water quality index (WQI) was determined based on the water quality index as below (Eq. 4):

$$
\begin{aligned}
\mathrm{WQI} & =(0.22 \times \mathrm{SIDO})+(0.19 \times \mathrm{SIBOD})+(0.16 \times \mathrm{SICOD}) \\
& +(0.15 \times \mathrm{SIAN})+(0.16 \times \mathrm{SITSS})+(0.12 \times \mathrm{SIpH})
\end{aligned}
$$

where:

$$
\begin{aligned}
& \text { SIDO = Sublndex DO (\% saturation }) \\
& \text { SIBOD = Sublndex BOD } \\
& \text { SICOD = Sublndex COD } \\
& \text { SIAN = Sublndex NH } \mathrm{NH}_{3}-\mathrm{N} \\
& \text { SISS = Sublndex SS } \\
& \text { SipH = Sublndex pH }
\end{aligned}
$$

Statistical analysis was conducted by using IBM SPSS Statistics 20. Two-way ANOVA was conducted for comparing water quality parameter at different stations and sampling times. Correlation analysis was also conducted to determine the relationship between physico-chemical and biological parameters.

\section{Results}

\section{Physico-chemical parameters}

Mean value for total suspended solid (TSS) for two sampling times is shown in the Figure $2 a$. TSS ranged from $1.67 \mathrm{mg} / \mathrm{L}$ to $8.17 \mathrm{mg} / \mathrm{L}$. The average value of TSS is 4.15 $\pm 0.48 \mathrm{mg} / \mathrm{L}$ and this value is categorized under Class I of NWQS. Based on the Twoway analysis of variance (ANOVA) result, there is no significantly different between TSS versus station and sampling time $(\mathrm{P}>0.05, \mathrm{P}=0.746)$.

Figure $2 b$ presents the mean value for ammoniacal nitrogen $\left(\mathrm{NH}_{3}{ }^{-} \mathrm{N}\right)$ for both sampling times. It was found that $\mathrm{NH}_{3} \mathrm{~N}$ were ranged from $0.03 \mathrm{mg} / \mathrm{L}$ to $0.31 \mathrm{mg} / \mathrm{L}$ with an average value of $0.18 \pm 0.04 \mathrm{mg} / \mathrm{L}$ and falls under Class I of NWQS. Two-way analysis of variance (ANOVA) shows that there is significantly different between $\mathrm{NH}_{3}{ }^{-}$ $\mathrm{N}$ and station $(\mathrm{P}<0.05, \mathrm{P}=0.000)$. There is also significant difference between $\mathrm{NH}_{3} \mathrm{~N}$ and sampling times $(\mathrm{P}<0.05, \mathrm{P}=0.038)$. Significantly different was also found between the effect of different stations and different sampling times on $\mathrm{NH}_{3} \mathrm{~N}(\mathrm{P}<0.05$, $\mathrm{P}=0.037$ ).

Mean value for biological oxygen demand (BOD) for two sampling times is shown in Figure $3 a$ is ranged from $0.04 \mathrm{mg} / \mathrm{L}$ to $1.42 \mathrm{mg} / \mathrm{L}$. The average value of BOD is $0.78 \pm 0.14 \mathrm{mg} / \mathrm{L}$, categorized under Class I of NWQS. There is no significantly 
different between BOD and sampling times $(\mathrm{P}>0.05, \mathrm{P}=0.189)$. However, there is significant difference between BOD and station $(\mathrm{P}<0.05, \mathrm{P}=0.000)$.

Figure $3 b$ shows the mean value for chemical oxygen demand (COD) that were ranged from $0.33 \mathrm{mg} / \mathrm{L}$ to $1.67 \mathrm{mg} / \mathrm{L}$, with an average value of $.64 \pm 0.22 \mathrm{mg} / \mathrm{L}$ (Class I). Two-way analysis of variance (ANOVA) shows that there is no significant difference between COD with station and sampling time $(\mathrm{P}>0.05, \mathrm{P}=0.656)$.

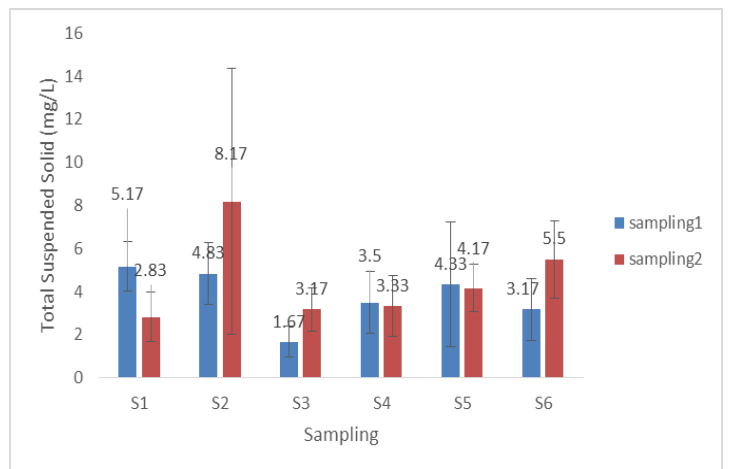

$\mathbf{a}$

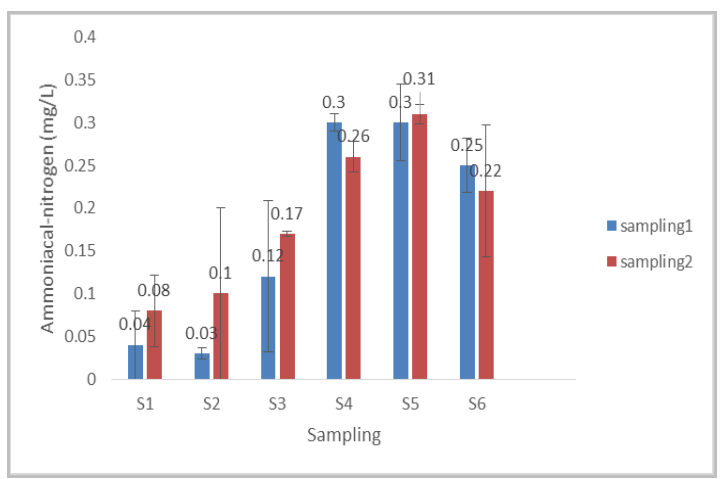

b

Figure 2. (a) TSS values for six sampling stations; (b) Ammoniacal nitrogen values for six sampling stations, where; the upstream (S1 and S2), the middle stream (S3 and S4) and the downstream (S5 and S6)

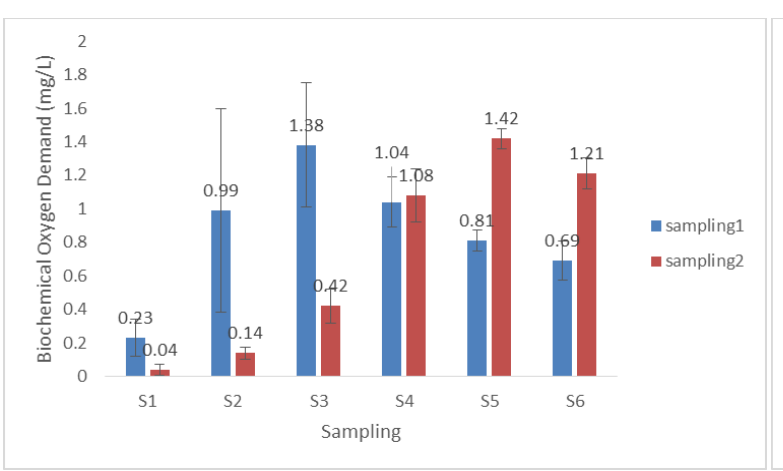

$\mathbf{a}$

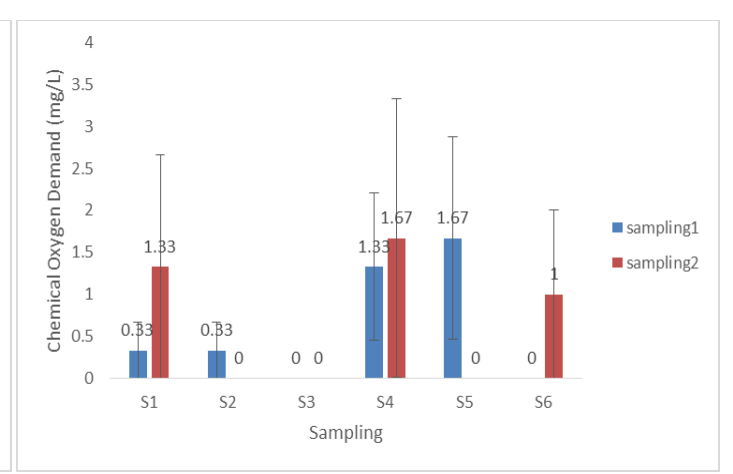

b

Figure 3. (a) Biochemical oxygen demand for six sampling stations; (b) Chemical oxygen demand for six sampling stations, where; the upstream (S1 and S2), the middle stream (S3 and S4) and the downstream (S5 and S6)

$\mathrm{pH}$ was ranged between 5.00 to 6.8 with an average of $5.60 \pm 0.67$, classified under Class III and IV for the first and second samplings, respectively (Fig. 4a). A significantly different was observed between $\mathrm{pH}$ and sampling times and station $(\mathrm{P}<0.05, \mathrm{P}=0.025)$ and $(\mathrm{P}<0.05, \mathrm{P}=0.000)$, respectively. Mean value for temperature for two sampling times is shown in Figure $4 b$ ranged from 20.76 to $21.49^{\circ} \mathrm{C}$. There is significant difference between temperature and sampling times $(\mathrm{P}<0.05, \mathrm{P}=0.000)$ as well as between temperature and station $(\mathrm{P}<0.05, \mathrm{P}=0.000)$.

It was found that the conductivity for both sampling times were ranged from 0.013 $\mathrm{mS} / \mathrm{cm}$ to $0.017 \mathrm{mS} / \mathrm{cm}$ (Fig. $5 a$ ). The average conductivity is $0.0014 \pm 0.0003 \mathrm{mS} / \mathrm{cm}$ and classified in Class I and IIA. Based on the result, there is no significant difference 
between conductivity and sampling times $(\mathrm{P}>0.05, \mathrm{P}=0.292)$, whereas there is significant difference between conductivity and station $(\mathrm{P}<0.05, \mathrm{P}=0.006)$. For dissolve oxygen, the mean value for both sampling times were ranged from $5.32 \mathrm{mg} / \mathrm{L}$ to $7.86 \mathrm{mg} / \mathrm{L}$ as shown in Figure $5 b$. The average DO is $6.60 \pm 0.29 \mathrm{mg} / \mathrm{L}$ (Class IIA and IIB). There is no significantly different between $\mathrm{DO}$ and sampling times $(\mathrm{P}>0.05$, $\mathrm{P}=0.078)$. However, there is significant difference between $\mathrm{DO}$ and station $(\mathrm{P}<0.05$, $\mathrm{P}=0.000)$.

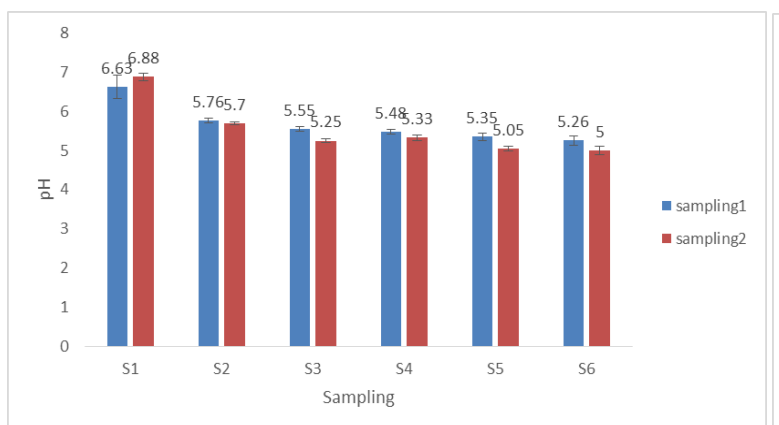

a

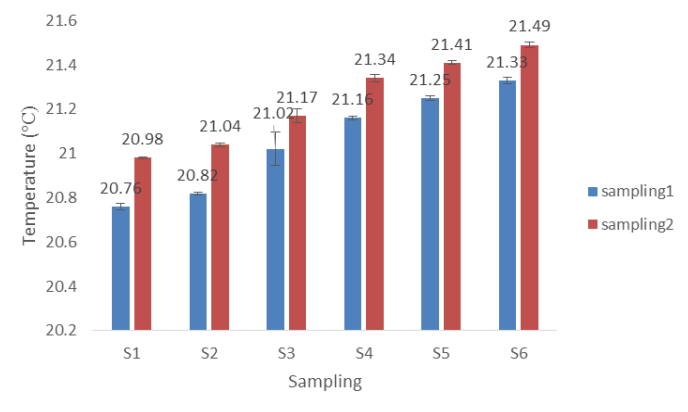

b

Figure 4. (a) $p H$ values for six sampling stations; (b) Temperature values for six sampling stations, where; the upstream (S1 and S2), the middle stream (S3 and S4) and the downstream (S5 and S6)

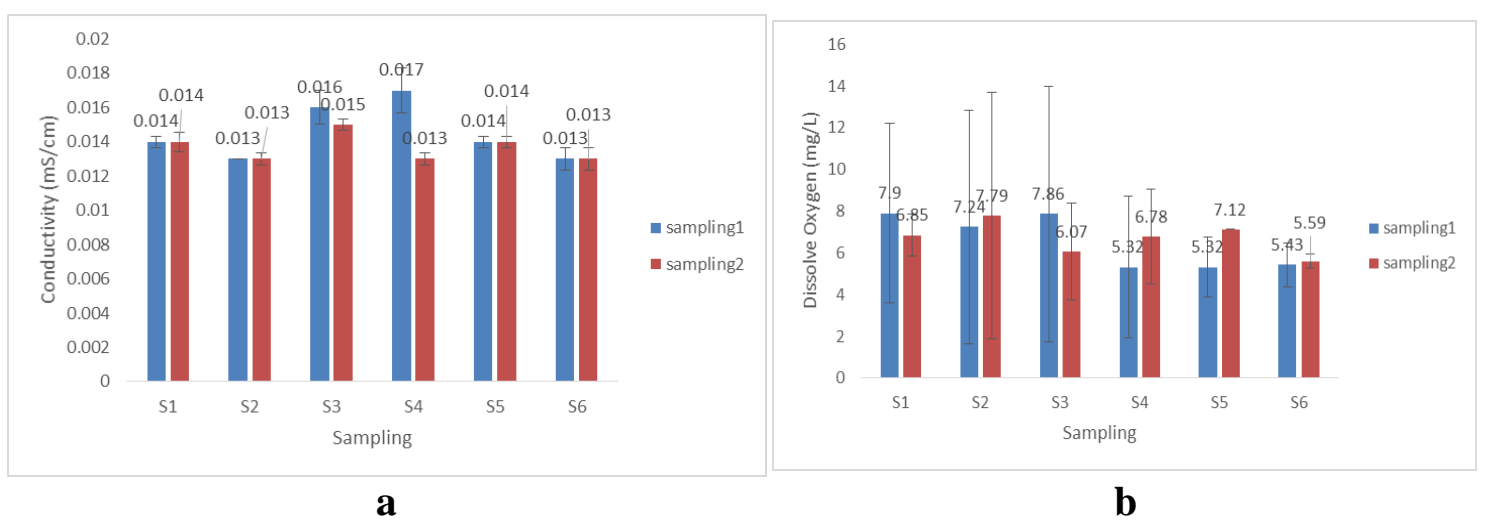

Figure 5. (a) Conductivity values for six sampling stations; (b) Dissolved oxygen values for six sampling stations, where; the upstream (S1 and S2), the middle stream (S3 and S4) and the downstream (S5 and S6)

Figure 6(a) shows the mean value for salinity for two times sampling ranged from 0.003 to 0.01 with an average of $0.007 \pm 0.001$ (Class I). No significantly different between salinity with station and sampling time was observed $(\mathrm{P}>0.05, \mathrm{P}=0.813)$. The mean value for total dissolved solid ranged from $0.009 \mathrm{~g} / 1$ to $0.011 \mathrm{~g} / \mathrm{l}$ (Fig. 6b). The average of TDS is $0.009 \pm 0.0001$ and classified under Class I. There is no significant difference between TDS and sampling times $(\mathrm{P}>0.05, \mathrm{P}=0.423)$, while significantly different was found between TDS and station $(\mathrm{P}<0.05, \mathrm{P}=0.032)$.

Water Quality Index (WQI) for all stations times is shown in Figure 7. WQI has been considered as one criterion for surface water classifications, based on the use of 
standard parameters for water characterization. This index is a numeric expression used to transform large quantities of water characterization data into a single number, which represents the water quality level (Mohamad Ali, 2010). The WQI values recorded were ranged from 85.45 to 94.86 with the highest WQI recorded at station 2, while the lowest WQI was measured at station 4 . The results show that WQI obtained from this study fall under Class I (clean category). Overall, the WQI value of Tekala River was classified under Class II which indicated as clean.

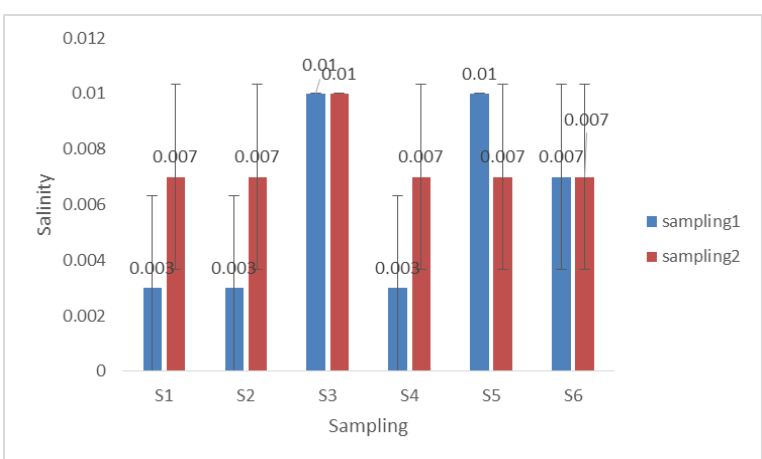

a

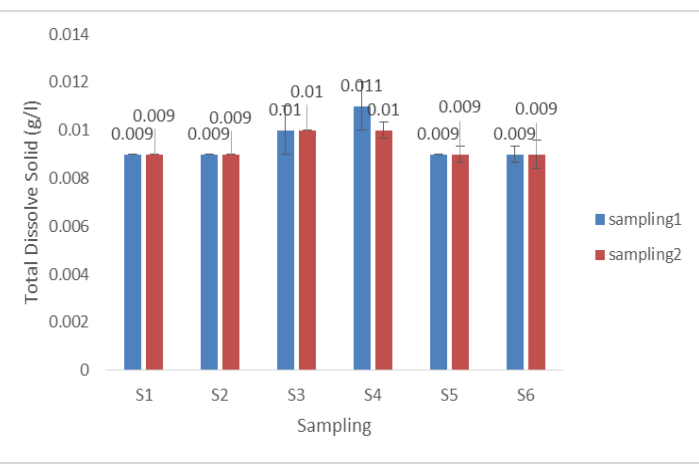

b

Figure 6. (a) Salinity values for six sampling stations; (b) Total dissolved solid values for six sampling stations, where; the upstream (S1 and S2), the middle stream (S3 and S4) and the downstream (S5 and S6)

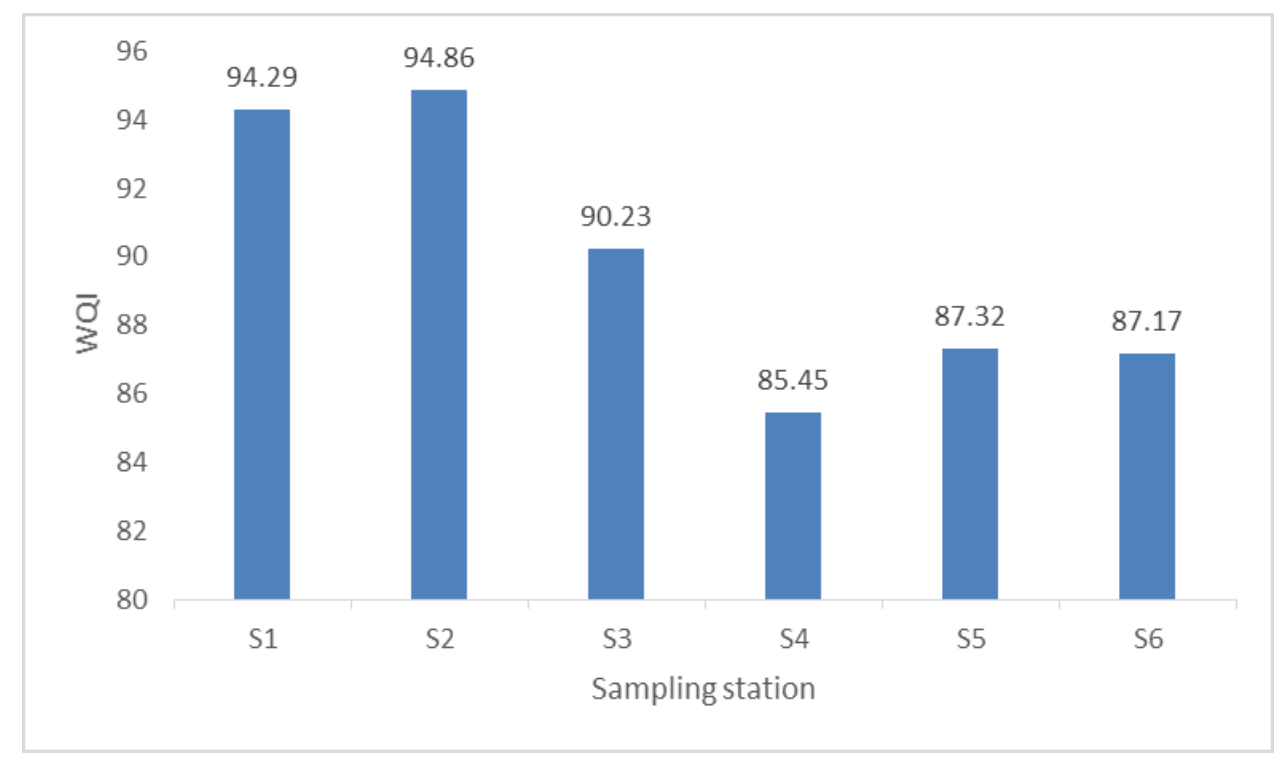

Figure 7. WQI value for six sampling stations

\section{Biological parameter}

Mean value for $E$. coli and total coliform for two sampling times are shown in Figures $8 a$ and $8 b$. E. coli and total coliform values were ranged from 1 to $16 \mathrm{cfu} / \mathrm{ml}$ and 3 to $48 \mathrm{cfu} / \mathrm{ml}$, respectively. The average value for $E$. coli and total coliform are $8 \pm$ $2 \mathrm{cfu} / \mathrm{ml}$ and $21 \pm 4 \mathrm{cfu} / \mathrm{ml}$, respectively and both are classified under Class I. Pearson's 
correlation was conducted to examine relationship between E. coli and coliform with the physico-chemical parameters (Table 1). Based on the test, there is relationship between $E$. coli with $\mathrm{NH}_{3}{ }^{-} \mathrm{N}$, temperature and DO. For coliform, there is relationship between coliform with $\mathrm{pH}$ and BOD.

\section{Macroinvertebrate}

Total value for macroinvertebrate for two sampling times is shown in Figure 9. The abundance of macroinvertebrate was ranged from 10 to 68 (Fig. 9). Pearson's correlation was conducted to examine the relationship between abundance of macroinvertebrate with the physico-chemical parameters (Table 2). Based on the test, there is relationship between abundance of macroinvertebrate with temperature of the river.

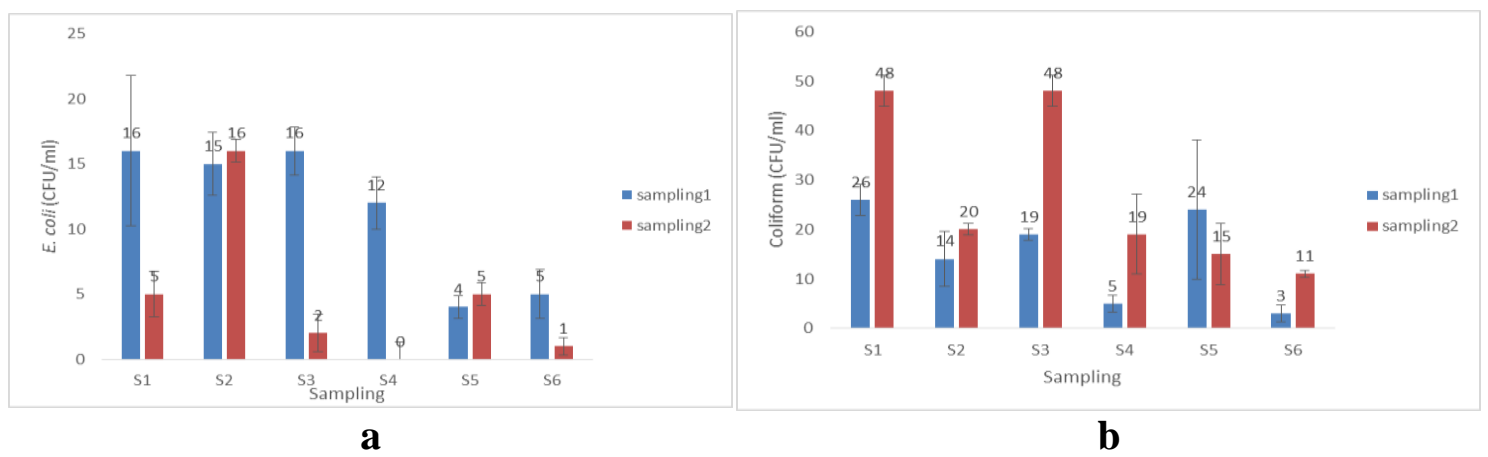

Figure 8. (a) E. coli values for six sampling stations; (b) Coliform values for six sampling stations, where; the upstream (S1 and S2), the middle stream (S3 and S4) and the downstream

(S5 and S6)

Table 1. Pearson's correlation between E. coli and coliform with physcio-chemical parameters

\begin{tabular}{|c|c|c|c|c|c|c|c|c|c|c|c|c|}
\hline PARAMETER & E.coli & Coliform & TSS & BOD & $\mathrm{NH}_{3} \mathrm{~N}$ & COD & $\mathrm{pH}$ & Temperature & Conductivity & DO & Salinity & TDS \\
\hline E.coli & 1 & & & & & & & & & & & \\
\hline Coliform & -0.19 & 1 & & & & & & & & & & \\
\hline TSS & 0.15 & -0.12 & 1 & & & & & & & & & \\
\hline BOD & -0.03 & $-0.47 * *$ & -0.094 & 1 & & & & & & & & \\
\hline $\mathrm{NH}_{3} \mathrm{~N}$ & $-0.43^{* *}$ & -0.102 & 0.111 & 0.256 & 1 & & & & & & & \\
\hline COD & -0.25 & 0.206 & -0.229 & 0.089 & 0.118 & 1 & & & & & & \\
\hline $\mathrm{pH}$ & 0.29 & $0.477^{* *}$ & -0.019 & $-0.56 * *$ & -0.287 & -0.06 & 1 & & & & & \\
\hline Temperature & $-0.67 * *$ & -0.297 & -0.022 & $0.377^{*}$ & $0.591^{* *}$ & 0.139 & $-0.75 * *$ & 1 & & & & \\
\hline Conductivity & 0.02 & 0.021 & -0.206 & 0.179 & 0.111 & -0.03 & -0.083 & 0.108 & 1 & & & \\
\hline DO & $0.53^{* *}$ & 0.222 & -0.053 & -0.157 & $-0.49 * *$ & -0.05 & $0.371^{*}$ & $-0.550^{* *}$ & -0.230 & 1 & & \\
\hline Salinity & -0.21 & 0.086 & $-0.043^{* *}$ & 0.112 & -0.003 & 0.040 & -0.231 & 0.190 & 0.014 & -0.08 & 1 & \\
\hline TDS & 0.02 & -0.134 & -0.114 & 0.111 & 0.067 & 0.110 & -0.164 & 0.149 & $0.748^{* *}$ & -0.31 & 0.022 & 1 \\
\hline
\end{tabular}




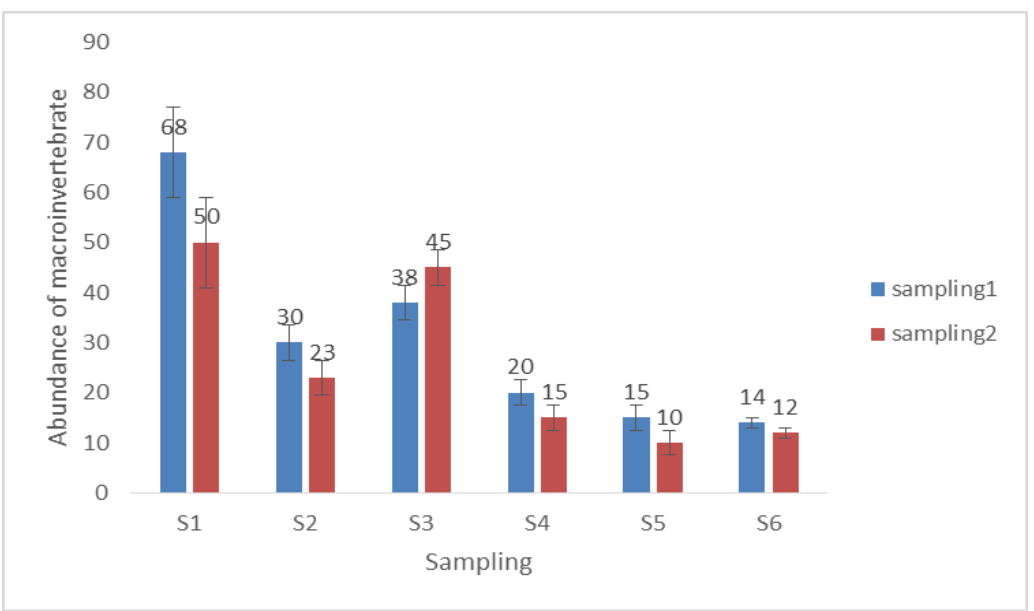

Figure 9. Abundance of macroinvertebrate for six sampling stations, where; the upstream (S1 and S2), the middle stream (S3 and S4) and the downstream (S5 and S6)

Table 2. Pearson's correlation between abundance of macroinvertebrate with physicochemical parameters

\begin{tabular}{|c|c|c|c|c|c|c|c|c|c|c|c|}
\hline PARAMETER & $\mathrm{X}$ & TSS & $\mathrm{NH} 3 \mathrm{~N}$ & COD & $\mathrm{pH}$ & Temperature & Conductivity & DO & Salinity & TDS & BOD \\
\hline $\mathrm{X}$ & 1 & & & & & & & & & & \\
\hline TSS & 0.054 & 1 & & & & & & & & & \\
\hline $\mathrm{NH} 3 \mathrm{~N}$ & -0.523 & -0.405 & 1 & & & & & & & & \\
\hline COD & -0.310 & -0.207 & 0.404 & 1 & & & & & & & \\
\hline $\mathrm{pH}$ & 0.441 & -0.183 & -0.322 & -0.045 & 1 & & & & & & \\
\hline Temperature & $-0.633^{*}$ & -0.098 & $0.692^{*}$ & 0.250 & $-0.807 *$ & 1 & & & & & \\
\hline Conductivity & -0.062 & -0.437 & 0.168 & -0.149 & 0.017 & -0.058 & 1 & & & & \\
\hline DO & 0.141 & 0.162 & $-0.639 *$ & -0.198 & -0.447 & -0.518 & -0.122 & 1 & & & \\
\hline Salinity & -0.440 & -0.269 & 0.299 & -0.007 & -0.369 & 0.509 & 0.033 & -0.121 & 1 & & \\
\hline TDS & -0.302 & -0.356 & 0.202 & 0.292 & -0.214 & -0.120 & $0.786^{* *}$ & -0.221 & -0.039 & 1 & \\
\hline BOD & -0.217 & -0.158 & 0.244 & 0.147 & $-0.692^{*}$ & $-0.587^{*}$ & 0.202 & -0.140 & -0.084 & 0.089 & 1 \\
\hline
\end{tabular}

${ }^{*}$ Correlation is significant at 0.01 level (2-tailed)

${ }^{*}$ Correlation is significant at 0.05 level (2-tailed)

\section{Discussion}

\section{Physico-chemical parameters}

Total Suspended Solids (TSS) are solids in water include a wide variety of material, such as silt, decaying plant and animal matter, industrial wastes, and sewage. High concentrations of suspended solids can cause many problems for stream health and 
aquatic life (Bilotta and Brazier, 2008). According to Wood and Armitage (1997), suspended solid in the river may be due to bank erosion, sediment load and anthropogenic activities or due to runoff from surrounding areas. In second sampling, station 2 surrounded by dense vegetation, thus recorded the highest TSS. Vegetation can reduce the erosion and increase sediment entrapment. However, there is no significant different between TSS with station and sampling time. The maximum threshold limit of TSS for Malaysian rivers which support aquatic life is $150 \mathrm{mg} / \mathrm{l}$ (Al-Badaii et al., 2013). TSS value recorded in this study are within the range of the limit.

Ammoniacal nitrogen $\left(\mathrm{NH}_{3} \mathrm{~N}\right)$ is a common pollutant in freshwater ecosystem and it is frequently found associated with organic compound or sometimes from industrial effluents (Alabaster and Lloyd, 1982; Magdalena et al., 2015). Abdel-Raouf (2012) stated that the presence of $\mathrm{NH}_{3}{ }^{-} \mathrm{N}$ in the water is mainly originated from the domestic sewage and waste water from certain types of industries. Ammoniacal nitrogen indicates nutrient status, organic enrichment and health of water body (Radojevic et al., 2007). Higher $\mathrm{NH}_{3}{ }^{-} \mathrm{N}$ values can be toxic to fish, but in small concentrations, it could serve as nutrients for excessive growth of algae (Al-Badaii et al., 2013). There is significant different between $\mathrm{NH}_{3} \mathrm{~N}$ with station and sampling times implying $\mathrm{NH}_{3} \mathrm{~N}$ is influenced by sampling location and time of sampling. The maximum threshold level of $\mathrm{NH}_{3} \mathrm{~N}$ for Malaysian rivers which support aquatic life is $0.9 \mathrm{mg} / \mathrm{l}$. The value of $\mathrm{NH}_{3} \mathrm{~N}$ obtained from this study is still within the range.

Biochemical Oxygen Demand (BOD) is a measurement of the amount of dissolved oxygen used by aerobic microorganisms when decomposing organic matter in water. It is a measure of the quantity of oxygen used by microorganisms in the oxidation of organic matter. Microorganisms such as bacteria are responsible for decomposing organic waste. When organic matter such as dead plants, leaves, grass clippings, manure, sewage or even food waste is present in a water supply, the bacteria will begin the process of breaking down this waste. When this happens, much of the available dissolved oxygen is consumed by aerobic bacteria, affecting oxygen level needed for other aquatic organisms (USGS, 2016).

If there is a large quantity of organic waste in the water supply, there will also be a lot of bacteria present working to decompose this waste. In this case, the demand for oxygen will be high so the BOD level will be higher. When BOD levels are high, dissolved oxygen levels decrease because the oxygen that is available in the water is being consumed by the bacteria (Al- Badaii et al., 2013). Since less dissolved oxygen is available in the water, fish and other aquatic organisms may not survive. If there is no organic waste present in the water, there will be fewer bacteria present to decompose it and thus the BOD will tend to be lower and the DO level will be higher.

Chemical Oxygen Demand (COD) is a measurement of the oxygen required to oxidize soluble and particulate organic matter in water (Boyd, 1973; Kunlasak et al., 2013). It is used to measure the total quantity of oxygen-consuming substances in the complete chemical breakdown of organic substances in water. It does not differentiate between biologically available and inert organic matter. COD measurements can be made in a few hours while BOD measurements take five days (Othman et al., 2012). Generally, the lower COD level indicates a low level of pollution, while the high level of COD points out the high level of pollution of water in the study area (Al-Badaii et al., 2013). The COD value obtained in this study is low indicating this river has low level of pollution. 
$\mathrm{pH}$ of a water sample is a measure of the concentration of hydrogen ions (Tank and Chippa, 2013). If the $\mathrm{pH}$ of water is too high or too low, most of the aquatic organisms will not be able to adapt to the extreme condition. $\mathrm{pH}$ can also affect the solubility and toxicity of chemicals and heavy metals in the water. Various concentration of solution, solid or gaseous that enters into river can influence $\mathrm{pH}$ of the river due to reaction of dissociation which may produce $\mathrm{H}+$ or $\mathrm{OH}$ - ions (Chang et al., 1983; Lelis et al., 2016). Based on the result, $\mathrm{pH}$ ranged from 5.00 to 6.88. There is significance different between $\mathrm{pH}$ with station and sampling times indicating $\mathrm{pH}$ is influenced by sampling location and time of sampling. $\mathrm{pH}$ slightly decreased from station 1 to station $6 . \mathrm{pH}$ of water body can be affected by several factors. One of the factors is the amount of plant growth and organic material within a body of water. Carbon dioxide is released when this material is decomposed. The carbon dioxide combines with water to form carbonic acid. Although this is a weak acid, large amounts of it will lower the $\mathrm{pH}$. Decaying vegetation produces organic acids, thus change the $\mathrm{pH}$ of the river (Gasim et al., 2007). Station 1 to station 6 were surrounded by vegetation. Different station may have different rate of decaying vegetation. This might explain the decreased of $\mathrm{pH}$ from station 1 to station 6 . Rainfall could also affect $\mathrm{pH}$ of water body due to the interaction with carbon dioxide molecules in the atmosphere. This creates $\mathrm{H}_{2} \mathrm{CO}_{3}$ in the raindrops, lowering the $\mathrm{pH}$ value of rainwater. A pH level of 5.65, though acidic, is not considered acid rain. Acid rain requires a $\mathrm{pH}$ below 5.0. If rain falls on a poorly buffered water source, it can decrease the $\mathrm{pH}$ of nearby water through runoff.

Water temperature is one of the most important characteristics of an aquatic system. It affects dissolved oxygen levels, species composition, chemical and biological processes (Tank and Chippa, 2013). A change in water temperature can affect the general health of the aquatic organisms, thus changing the quality of the stream. There is significant difference between temperature with sampling times and station. The temperature of surface water is usually between $0{ }^{\circ} \mathrm{C}$ and $30^{\circ} \mathrm{C}$. The lowest temperature was recorded at station 1 and the highest at station 6 for both samplings. There is slightly increased of temperatures from station 1 to station 6. Usually there is an increase in temperature from the first station to the last station (Bordalo et al., 2001). Water temperature varies along the length of a river with latitude and elevation. The geographical location of sampling stations are differ on elevation and environment. Station 1 and station 2 were located in upstream, station 3 and station 4 in the middle meanwhile stations 5 and 6 in the downstream. Vegetation cover may influence water surface temperature. Area from station 1 to station 6 were covered by vegetation. However, the vegetation in the upstream was denser than middle and downstream. The vegetation acts as protection to surface water from directly being heated by solar radiation. The forest canopies will shield the water surface from the emission of long wave radiation from the sun. Denser vegetation gives more protection to the surface water thus this might explain the reason why station 1 had low temperature compared to other stations. Human activities in the surrounding area might also influence the water temperature. The middle and downstream had a lot of human contact as the river is a recreational area. Downstream area vegetation had some disruption as a lot of facilities being built in this area. Water temperature can also be influenced by variation of precipitation. According to Shuhaimi-Othman et al. (2008) large volume of water inputs and higher flow rate were responsible for cooling down the river temperature. There is only little difference of temperature between first and second samplings. 
Conductivity can be defined as an ability of the aquatic system to transmit electric current based on the level of dissolved ions in a water body. Conductivity in water is affected by the presence of inorganic dissolved solids such as chloride, nitrate, sulfate and phosphate anions or sodium, magnesium, calcium, iron, and aluminum cations. Conductivity normally coinciding with the level of dissolved salt in water and has a strong correlation with salinity. An increasing in level of dissolved salt would result an increased in conductivity. There is slightly difference of salinity based on times and location of the sampling in this study. Based on the result, there is no significance different between conductivity and sampling times but there is significant different between conductivity and different station which means conductivity is influenced by sampling location. Conductivity in streams and rivers is affected primarily by the geology of the area through which the water flows. Streams that run through areas with granite bedrock tend to have lower conductivity because granite is composed of more inert materials that do not ionize when washed into the water. On the other hand, streams that run through areas with clay soils tend to have higher conductivity because of the presence of materials that ionize when washed into the water. Soil and rocks release dissolved solids into the waters that flow through or over them. Therefore, the geology of a certain area will determine the conductivity. Most streams have a fairly constant range of conductivity under normal circumstances. Therefore, significant changes in conductivity can be an indicator that a discharge or some other source of pollution has entered the water. This might explain the reason why conductivity for different sampling times is constant and the difference can be seen mostly based on the sampling location. The conductivity was ranged from $0.013 \mathrm{mS} / \mathrm{cm}$ to $0.017 \mathrm{mS} / \mathrm{cm}$. This is considered low and does not affect the water quality (Suki et al., 1988; Rashid et al., 2013).

Dissolved oxygen (DO) measures the amount of gaseous oxygen dissolved in an aqueous solution. Oxygen gets into water by diffusion from the surrounding air, by aeration and as a waste product of photosynthesis from phytoplankton, algae, seaweed and other aquatic plants (Othman et al., 2012). The amount of dissolved oxygen varies depending on temperature, pressure and salinity. Solubility of oxygen decreases as temperature increases. This is due to the fact that warmer surface water requires less dissolved oxygen to reach $100 \%$ air saturation compared to cooler water. There is negative correlation of DO and temperature which means higher temperature will reduce DO level. Temperature slightly increased from station 1 to station 6 and the DO level recorded is slightly reduced from station 1 to station 6. Dissolved oxygen decreases exponentially as salt levels increase. There is significance difference between DO and station. In freshwater systems such as lakes, rivers and streams, dissolved oxygen concentrations will vary by season, location and water depth and it will decrease with higher temperature, salinity and elevation (Beale et al., 2000). Oxygen concentrations vary with the volume and velocity of water flowing in a stream. Faster flowing water areas, such as in a mountain stream or large river tend to be more oxygen rich because more oxygen enters the water from the atmosphere in those areas than in slower and stagnant areas. Oxygen is more easily dissolved into water at low altitudes that at high altitudes. Oxygen is also more easily dissolved into water with low levels of dissolved or suspended solids. Removal of riparian vegetation may lower oxygen concentrations due to increased water temperature resulting from a lack of canopy shade and increased suspended solids resulting from erosion of bare soil. Upstream area has 
faster flowing water compared to lower area thus this might explain why level of DO is higher in upstream area.

Salinity is the total concentration of all dissolved salts in water. Freshwater contains few salts and thus has low salinity. Most of natural freshwater do not show much different on level of salinity unless there are additional discharged from surrounding environment into the river. The salinity value recorded from this study is low thus it would not have huge impact in the environment.

Total dissolved solid (TDS) is a measure of the amount of material dissolved in a water sample. This material includes dissolved minerals and organic matter but can also include contaminants. There is significant difference found between TDS with station. TDS is influenced by sampling location. TDS can vary spatially and temporally due to natural and anthropogenic factors such as climate, soil type, relief, land use and human activities (Augustijn et al., 2011). TDS in water supplies originated from natural sources, sewage, urban and agricultural run-off and industrial wastewater. Water containing TDS concentrations below $1,000 \mathrm{mg} / 1$ is usually acceptable but water with extremely low concentrations of TDS may also be unacceptable to consumers because of its flat, insipid taste to consumers. No recent data on health effects associated with the ingestion of TDS in drinking-water appear to exist (WHO, 2004).

Water quality index (WQI) provides relative indication of the quality of water. A river with WQI value in the ranges $0-59$ is considered polluted, 60-80 is considered slightly polluted and 81-100 is considered the water body is clean. A higher value indicates a better quality of water (Suki et al., 1988; Rashid et al., 2013). From this study, the average WQI calculated at each sampling station for both sampling times are described as follows: Station S1 (94.29: Class I), S2 (94.86: Class I), S3 (90.23: Class II), S4 (85.45: Class II), S5 (87.32: Class II) and S6 (87.17: Class II) (Fig. 4). The results show that WQI obtained from this study fall under Class I (clean category). Overall, the WQI value of Tekala River was classified under Class II which indicated as clean. Generally, WQI tends to decrease from upstream to downstream of river due to increasing of pollutant. WQI recorded slightly reduced from station 1 to station 6 .

\section{Biological parameter}

E. coli is mainly originated from the feces of warm blooded organism. This type of bacteria usually entered into water surface by run-off from agricultural and residential areas (Pearson et al., 1987; Inatsuka et al., 2010). From the first sampling, there is a decrease of $E$. coli from station 1 to station 6. Second sampling recorded less number of E. coli. There is correlation relationship found between $E$. coli and $\mathrm{NH}_{3}{ }^{-} \mathrm{N}$, temperature and DO. It is reported that fecal coliform levels were lower at higher temperature, high dissolved oxygen and high $\mathrm{pH}$ implying that one of the fecal coliform sources could be related to human recreational activities (Al-Badaii et al., 2013). This might explain the downtrend of bacteria from first station to the last station. Since this river is a recreational area, it probably potentially exposed to fecal contamination sources from human activities (swimming, camping) that cannot be detected by measuring physicochemical parameters alone.

From the first and second samplings, there is a decrease of coliform from station 1 to station 6. Second sampling recorded less number of coliform. There is correlation relationship found between coliform with $\mathrm{pH}$ and BOD. Water with lower $\mathrm{pH}$ value helps in maintaining the survival of indicator bacteria (Parhad et al., 1974; Mara, 2013). A study done by Šolić and Krstulović (1992) also suggested that the optimal pH value 
for coliform survival is between $\mathrm{pH} 6$ and $\mathrm{pH} 7$ and other $\mathrm{pH}$ value above or below these range can cause rapid decline in fecal coliform population. The bacteria population is influenced by favourable condition and food sources provided by the sediments for the bacteria (Davies et al., 1995). Lower temperature of surface water can cause rapid decline in coliform and E. coli population in the water (McDaniels et al., 1985; Pope et al., 2003).

\section{Macroinvertebrate}

Macroinvertebrates and water quality are interrelated to each other, as macroinvertebrates are a potential biological indicator of water quality. They are most frequently used in biomonitoring studies (Harikumar et al., 2014). Often many species within a community with varying sensitivities to stresses and relatively quick reaction times, resulting in a spectrum of graded, recognisable responses to environmental perturbation. The responses to different types of pollution have been established for many common species (Ollis et al., 2006). Stream communities are shaped by environmental influences at multiple spatial scales. Their distribution, interaction and adaptation can be influenced by abiotic factors which vary in space and time. Climate is one of the factors that influence population dynamics of aquatic insects (Nor Zaiha et al., 2015). In this study, the number of macroinvertebrate found is low. Most of the macroinvertebrate found belong to the same family. A study on surber net was conducted at the forested stream site by Wan Mohd Hafezul et al. (2016). They found very low species abundance was recorded by the surber net. Its small size makes it difficult to set on rough substrates in deep water and often results in the loss of large organisms that are fast enough to crawl out of the front of the sampler. Usually area disturbed within the surber net is exposed, providing an opportunity for aquatic fauna to escape (Wan Mohd Hafezul et al., 2016).

The most dominant insect found in all stations is water strider from family Gerridae. Based on the correlation test, there is relationship between abundance of macroinvertebrate and temperature. Water striders most prefer waters around $25{ }^{\circ} \mathrm{C}$. Large numbers can indicate moderate, or slightly polluted water quality. In the upstream area, a few mayfly from order Ephemeroptera was caught in station 4. Ephemeroptera is a group of aquatic insects which is sensitive to environmental interference and can only survive in clean and oxygen-rich waters. Therefore, they are often considered as good biological indicators of water quality (Nor Zaiha et al., 2015). The most significant environmental factor affecting life-history patterns, especially growth rates and the seasonal timing of aquatic insects, is water temperature. Mayfly is widely distributed in peninsular Malaysia. It inhabits upstream rivers of peninsular Malaysia. Low water temperature seemed to favor mayfly abundance. Predators, particularly fish, play a role in the mayfly community (Suhaila et al., 2016). In station 4, there is no fish found in fast flowing water thus mayfly might prefer the area. From station 3 to 6 , there is no more mayfly found. Station 3 has fish community, thus this area might not be preferred by mayfly. There is less human contact from station 1 to station 3, where visitor usually stay in area station 4 to station 6.

There are several other organisms that were found in the river such as freshwater shrimp, freshwater crabs and water penny. Freshwater crabs are one of the most ecologically important macro-invertebrate groups in tropical inland waters worldwide. These strictly freshwater decapods are found in almost all clean freshwater bodies in the tropics from moist lowland forests to rugged mountains. Crabs live in rivers, streams, 
waterfalls, wetlands, karsts, caves and many are semi-terrestrial. Almost all require pristine water conditions to survive and are excellent indicators of good water quality (Cumberlidge et al., 2009). Generally, it can be concluded that more abundant macroinvertebrate communities exist in the littoral zone than in the deeper river bed. The individual numbers are usually very low in the deep water zone which is dominated by continually shifting sand (Csányi et al., 2012). Type of food sources and physical properties of river determine the distribution of aquatic organisms (Cummins and Merritt, 1996).

\section{Conclusions}

From this study, physico-chemical parameters and biomonitoring analysis have been conducted to determine the status of water quality at Tekala River, Selangor. Water quality index for Tekala River were ranged from 85.45 to 94.86 , thus indicated that the water quality status for both sampling times and six sampling stations are classified under Class I and Class II. It was found that there is significance different between ammoniacal nitrogen, $\mathrm{pH}$ and temperature. Correlation was also found between several physico-chemical parameters with biological parameter. From the Pearson's correlation test, there is relationship between $E$. coli with ammoniacal nitrogen, temperature and DO. For coliform, there is relationship between coliform with $\mathrm{pH}$ and BOD. The data from this study was also compared with the National water quality standard (NWQS) and most parameters were classified under Class I to Class IIB, implying that this river is safe to be used for recreational purposes. It is recommended that further research on other parameters on this river to be conducted in order to get better assessment on the water quality.

Acknowledgement. Marlia Mohd Hanafiah was financed by the research grant (DIP-2017-006).

Conflict of interest. The authors confirm that this article content has no conflict of interest.

\section{REFERENCES}

[1] Abdel-Raouf, N., Al-Homaidan, A. A., Ibraheem, I. B. M. (2012): Microalgae and wastewater treatment. - Saudi Journal of Biological Sciences 19(3): 257-275.

[2] Al-Badaii, F., Shuhaimi-Othman, M., Gasim, M. B. (2013): Water quality assessment of the Semenyih River, Selangor Malaysia. - Journal of Chemistry 2013: 871056.

[3] Alabaster, J. S., Lloyd, R. (1982): Finely Divided Solids. Water Quality Criteria for Freshwater Fish. Second Edition. - Butterworth, London, UK, pp.1-20.

[4] APHA, A. (1980): WPCF, 1992. Standard Methods for the Examination of Water and Wastewater. $15^{\text {th }}$ Edition. - American Public Health Association, New York.

[5] Ashraf, M. A., Hanafiah, M. M. (2017): Recent advances in assessment on clear water, soil and air. - Environmental Science \& Pollution Research 24: 22753-22754.

[6] Augustijn, D., Fares, A., Tran, D. N. (2011): Temporal and spatial variations in total suspended and dissolved solids in the upper part of Manoa Stream, Hawaii. - Journal of Sustainable Watershed Science \& Management 1(1): 1-9.

[7] Beale, G. T. H., Beecham, R., Harris, K., O’Neill, D., Schroo, H., Tuteja, N. J., Williams, R. M. (2000): Salinity Predictions for NSW Rivers within the Murray-Darling Basin. Centre for Natural Resources, NSW Department of Land and Water Conservation, Australia. 
[8] Bilotta, G. S., Brazier, R. E. (2008): Understanding the influence of suspended solids on water quality and aquatic biota. - Water Research 42(12): 2849-2861.

[9] Bordalo, A. A., Nilsumranchit, W. Chalermwat, K. (2001): Water quality and uses of the Bangpakong River (Eastern Thailand). - Water Research 35(15): 3635-3642.

[10] Boyd, C. E. (1973): The chemical oxygen demand of waters and biological materials from ponds. - Transactions of the American Fisheries Society 102(3): 606-611.

[11] Chang, H. C., Healy, T. W., Matijević, E. (1983): Interactions of metal hydrous oxides with chelating agents: III. Adsorption on spherical colloidal hematite particles. - Journal of Colloid and Interface Science 92(2): 469-478.

[12] Csányi, B., Szekeres, J., György, A. I., Szalóky, Z., Falka, I. (2012): Methodology of macroinvertebrate survey on large rivers: A case study on the Romanian Lower Danube. - Water Research and Management 2(2): 25-40.

[13] Cumberlidge, N., Ng, P. K., Yeo, D. C., Magalhães, C., Campos, M. R., Alvarez, F., Naruse, T., Daniels, S. R., Esser, L. J., Attipoe, F. Y., Clotilde-Ba, F. L. (2009): Freshwater crabs and the biodiversity crisis: importance, threats, status, and conservation challenges. - Biological Conservation 142(8): 1665-1673.

[14] Cummins, K. W., Merritt, R. W. (1996): Ecology and Distribution of Aquatic Insects. An Introduction to the Aquatic Insects of North America. - Kendal/Hunt Publishing Company, Iowa.

[15] Davies, C. M., Long, J. A., Donald, M., Ashbolt, N. J. (1995): Survival of fecal microorganisms in marine and freshwater sediments. - Applied and Environmental Microbiology 61(5): 1888-1896.

[16] Gasim, M. B., Ismail, B. S., Toriman, E., Mir, S. I., Chek, T. C. (2007): A physicochemical assessment of the Bebar River, Pahang, Malaysia. - Global Journal of Environmental Research 1(1): 7-11.

[17] Gelover, S., Gomez, L. A., Reyes, K., Leal, M. T. (2006): A practical demonstration of water disinfection using TiO2 films and sunlight. - Water Res 40: 3274-80.

[18] Harikumar, P. S. P., Deepak, R., Sabitha, A. R. (2014): Water Quality Assessment of Valapattanam River Basin in Kerala, India, using Macro-Invertebrates as Biological Indicators. - The Open Environmental \& Biological Monitoring Journal 6: 1-9.

[19] Inatsuka, C. S., Xu, Q., Vujkovic-Cvijin, I., Wong, S., Stibitz, S., Miller, J. F., Cotter, P. A. (2010): Pertactin is required for Bordetella species to resist neutrophil-mediated clearance. - Infection and Immunity 78(7): 2901-2909.

[20] Kunlasak, K., Chitmanat, C., Whangchai, N., Promya, J., Lebel, L. (2013): Relationships of dissolved oxygen with chlorophyll-a and phytoplankton composition in tilapia ponds. International Journal of Geosciences 4(05): 46.

[21] Lelis, D. F., Leão, V. A., Lima, R. M. F. (2016): Effect of EDTA on quartz and hematite flotation with starch/amine in an aqueous solution containing $\mathrm{Mn}^{2+}$ ions. - REMInternational Engineering Journal 69(4): 479-485.

[22] Magdalena, K., Grove, G. S., Bilotta, R. R., Woockman, J., Schwartz, S. (2015): Suspended sediment regimes in contrasting reference-condition freshwater ecosystems: Implications for water quality guidelines and management. - Science of the Total Environment 502: 481-492.

[23] Mara, D. (2013): Domestic Wastewater Treatment in Developing Countries. - Routledge, London.

[24] McDaniels, A. E., Bordner, R. H., Gartside, P. S., Haines, J. R., Brenner, K. P., Rankin, C. C. 1985. Holding effects on coliform enumeration in drinking water samples. Applied and Environmental Microbiology 50(4): 755-762.

[25] Millennium Development Goal (MDG) Report (2012): http://www.un.org/millenniumgoals/pdf/MDG\%20Report\%202012.pdf. - Accessed on 20 August 2016. 
[26] Mohamad Ali Fulazzaky, M. A., Seong, T. W., Masirin, M. I. M. (2010): Assessment of water quality status for the Selangor River in Malaysia. - Water, Air, and Soil Pollution 205: 63-77.

[27] Muhammad Mansoor, S., Awadh, O. A., Marlia, M. H., Muhammad Aqeel, A., Siti Norliyana, H. (2018): Study on migration of phenolic and volatile organic compounds from plastic pipes used in plumbing home networks into tap water. - Desalination and Water Treatment 112: 344-350.

[28] Nor Zaiha, A., Mohd Ismid, S. (2015): Temporal distribution of benthic macroinvertebrate communities from tropical forest stream in Gunung Pulai Recreational Forest, Johor, Peninsular Malaysia. - Sains Malaysiana 44(9): 1223-1228.

[29] Ollis, D. J., Dallas, H. F., Esler, K. J., Boucher, C. (2006): Bioassessment of the ecological integrity of river ecosystems using aquatic macroinvertebrates: an overview with a focus on South Africa. - African Journal of Aquatic Science 31(2): 205-227.

[30] Othman, F., Alaa Eldin, M. E., Mohamed, I. (2012): Trend analysis of a tropical urban river water quality in Malaysia. - Journal of Environmental Monitoring 14(12): 31643173.

[31] Parhad, N. M., Rao, N. U. (1974): Effect of pH on survival of Escherichia coli. - Journal Water Pollution Control Federation 46(5): 980-986.

[32] Pearson, R. D., Symes, P., Conboy, M., Weiss, A. A., Hewlett, E. L. (1987): Inhibition of monocyte oxidative responses by Bordetella pertussis adenylate cyclase toxin. - The Journal of Immunology 139(8): 2749-2754.

[33] Pope, M. L., Bussen, M., Feige, M. A., Shadix, L., Gonder, S., Rodgers, C., Chambers, Y., Pulz, J., Miller, K., Connell, K., Standridge, J. (2003): Assessment of the effects of holding time and temperature on Escherichia coli densities in surface water samples. Applied and Environmental Microbiology 69(10): 6201-6207.

[34] Radojevic, M., Abdullah, M. H., Aris, A. Z. (2007): Analisis Air. - Scholar Press, Puchong Selangor.

[35] Rashid, S. A. A., Gasim, M. B., Toriman, M. E., Juahir, H., Kamarudin, M. K. A., Azid, A., Aziz, N. A. A. (2013): Water quality deterioration of Jinjang River, Kuala Lumpur: Urban risk case water pollution. - The Arab World Geographer 16(4): 349-362.

[36] Shuhaimi-Othman, M., Mushrifah, I., Lim, E. C., Ahmad, A. (2008): Trend in metals variation in Tasik Chini, Pahang, Peninsular Malaysia. - Environmental Monitoring and Assessment 143(1-3): 345-354.

[37] Šolić, M., Krstulović, N. (1992): Separate and combined effects of solar radiation, temperature, salinity, and $\mathrm{pH}$ on the survival of faecal coliforms in seawater. - Marine Pollution Bulletin 24(8): 411-416.

[38] Suhaila, A. H., Che Salmah, M. R., Abu, H. A. (2016): Life history of Thalerosphyrus (Ephemeroptera: Heptageniidae) in tropical rivers with reference to the varying altitude. Tropical Life Sciences Research 27(1): 43.

[39] Suki, A., Yusoff, M., Mok, T. P. (1988): Water quality profile of Sg. Langat. - Pertanika 11(2): 273-281.

[40] Tank, S. K., Chippa, R. C. (2013): Analysis of water quality of Halena Block in Bharatpur Area. - International Journal of Scientific and Research Publication 3(3): 1-6.

[41] U.S. Geological Survey (USGS). (2016): The USGS Water Science School. http://water.usgs.gov/edu/earthwherewater.html. Accessed on 10 September 2016.

[42] Wan Mohd Hafezul, W. A. G., Che Salmah, M. R., Suhaila, A. H., Salman, A. A.-S. (2016): Efficiency of different sampling tools for aquatic macroinvertebrate collections in Malaysian streams. - Tropical Life Sciences Research 27(1): 115.

[43] WHO (2004): Guidelines for Drinking-Water Quality: Recommendations. - World Health Organization, Geneva.

[44] Wood, P. J., Armitage, P. D. (1997): Biological effects of fine sediment in the lotic environment. - Environmental Management 21(2): 203-217. 